\title{
Protective Role of Qurecitin against Zinc Oxide Nanoparticles Induced Hepatotoxicity
}

\section{Mona M. Lotfy ${ }^{1}$, Ibrahim A. Ibrahim ${ }^{2}$, Sherif Y. Saleh2, Marwa A. Elbeltagy2, Haytham A. Ali ${ }^{3}$}

${ }^{1}$ Master student faculty of Vet. Med. Suez Canal University, Ismailia, Egypt.

2Department of Biochemistry, Faculty of vet. Medicine, Suez Canal University, Ismailia, Egypt

3Department of Biochemistry, Faculty of vet. Medicine, Zagazig University, Zagazig, Egypt

\begin{tabular}{l} 
A R T I C L E I N F O \\
\hline Keywords:
\end{tabular}

ZnONPs, Qurecetin, liver, rats.

\begin{abstract}
A B S T R A C T
Background: The extensive use of nanoparticles in our life especially zinc oxide nanoparticles (ZnO NPs) in cosmetics, sun blockers, paints and food additives draw our attention toward their hepatotoxicity and the protective role of Qurecitin (QE).

Objective: the present study aimed to investigate the hepatotoxic effect of ZnONPs and the protective role of Qurecitin against it.

Results: I/P injection of ZnONPs in a dose of 200 and $400 \mathrm{mg} / \mathrm{kg}$ b.wt resulted in a significant increase in the serum levels of ALT, ALT and ALP with a significant increase in the hepatic MDA levels and decrease in non-enzymatic (GSH) and Enzymatic (GPx, GR, SOD and CAT) activities and their mRNA levels. Meanwhile, the cotreatment of ZnONPs with QE ameliorate the hepatic condition through decreasing the liver enzymes and MDA with increase in the antioxidant levels and their gene expression.

Conclusion: Taken together it can be concluded that QE has an ameliorative effect against ZnONPs hepatotoxicity.
\end{abstract}

\section{INTRODUCTION}

Nanotechnology has rapidly emerging industrial applications in medical, industrial, and military areas $(1,2)$. One of the most frequently used nanoparticles is Zinc oxide nanoparticles (ZnONPs); ZnONPs are most widely used in consumer products including semiconductors, catalysts, paints as well as food industry, cosmetic products, and sunscreen lotions, because of their efficient $\mathrm{UV}$ absorption properties of $\mathrm{ZnO}$ (3). The use of ZnONPs in food industry as additives and in packaging was related to their possible antimicrobial, fungicidal and anticancer properties (4). Meanwhile the excessive use of ZnONPs and frequent exposure resulted in more attention being paid to their potential toxicity, including cytotoxic, genotoxic, and proinflammatory effects $(5,6)$.
In the last decades, several reports was existed describing the toxic effects of ZnONPs on different tissues with a different routes of administrations and different doses (7-10). But till now many points about the mechanisms of toxicity and the possible routes of avoiding that toxicity is still unclear and needs more explanation.

In vivo studies concerned with the mechanism of toxicity owed it to the state of oxidative stress and free radicals observed after ZnONPs treatment in animal models $(10,11)$. Oxidative stress has been recognized as one of the most important cause of many diseases because free radicals and reactive oxygen species can damage the tissue and DNA integrity (12), that predispose the initiation of several diseases such as chronic heart 
diseases (CHD), neurodegenerative diseases and many others (13). Therefore an immediate attention is needed to prevent or decrease the exposure of substances causing oxidative stress.

Since antioxidants suppress the action of reactive oxygen species, these compounds have been used in the medical treatment of oxidative stress induced diseases (14).

Quercetin (QE) (3, 5, 7, 3', 4'-pentahydroxy-flavanone) is a plant-derived flavonoid, found mainly in fruits and vegetables. Several studies have indicated that QE may have anti-inflammatory and antioxidant properties due to its free radical scavenging and metal-chelating activities (15-17). QE has attracted much attention for its potential to prevent cardiovascular (18), neoplastic (19), and neurodegenerative (20) diseases.

In the light of the above mentioned, this work was designed aiming to study the hepatotoxic effect of ZnONPs and the possible protective role of $\mathrm{QE}$.

\section{Material and methods}

Chemical: ZnONPs: was purchased from faculty of science of Beni-Suef University which was a white powder with a measured ZnONPs content of purity $\geq 99.99 \%$ and size of nanoparticles was $27 \mathrm{~nm}$.

Quercetin (QE) and other chemicals were obtained from Sigma-Aldrich (St. Louis, MO, USA).

Animal Management: Rats of different groups were housed in different cages, fed on standard laboratory pellet and purified drinking water was provided ad libitum. The temperature of the experimental room was maintained at $25 \pm 3{ }^{\circ} \mathrm{C}$, and a $12 \mathrm{~h}$ light/12 h dark cycle was maintained. Oral dosing was carried out using an 18-gauge oral feeding needle. All experiments were carried out in accordance with the Egyptian laws and University guidelines for the care of experimental animals. All procedures of the current experiment have been approved by the Ethical Committee of the Faculty of Vet. Med. Suez Canal University Egypt.

Animal Selection and Grouping: Sixty male albino rats, with average age and weight at the beginning of the experiment (6 months and $130 \pm 10 \mathrm{~g}$ ). All experimental animals after acclimatization for two weeks before treatment, were divided into six groups $(n=10)$ : the first group served as a normal control and received normal saline $(0.5 \mathrm{ml} / \mathrm{kg} \mathrm{b}$. wt. $)$. The second group was daily administrated by $50 \mathrm{mg} / \mathrm{kg} \mathrm{b}$. wt. QE orally for one month according to (21). The third and fourth groups were intraproteinally injected with 200 and $400 \mathrm{mg} / \mathrm{kg}$ b. wt. of ZnONPs respectively every other day for one month according to (22). The fifth and sixth groups were orally administrated with $50 \mathrm{mg} / \mathrm{kg}$ b. wt. of $\mathrm{QE}$ and $\mathrm{I} / \mathrm{P}$ injected with 200 and $400 \mathrm{mg} / \mathrm{kg}$ b. wt. of ZnONPs every respectively every other day for one month. At the end of experimental period, all animals were deprived of food overnight and killed under mild anesthesia, blood and hepatic tissue were collected for biochemical and molecular analysis.

Sampling Protocol: Blood samples were collected from median canthus of eye and the sera $(\sim 1 \mathrm{ml})$ were separated by centrifugation and stored at $-20 \mathrm{oC}$ for biochemical investigation. Hepatic tissues were collected and divided into 3 parts, the first part was homogenized for further biochemical investigation. The second part kept in formalin $10 \%$ processed and stained with haematoxylin and eosin (H\&E) dyes for histopathological study using a light microscope according to (23). The third part of hepatic tissues was also taken on liquid nitrogen used for molecular analysis.

\section{Biochemical Analysis}

Serum ALT, AST, ALP and $\gamma$-GT were determined using spectrum Kits (Egyptian Company for Biotechnology, Cairo, Egypt REF: 265 002, 261 002, 263002 and 264002) following the manufacture instructions. Hepatic tissue homogenate 
was used for estimation of Malondialdehyde (MDA), CAT, SOD, GR and GPx activities (24).

\section{Molecular analysis:}

Total RNA was extracted from $30 \mathrm{mg}$ of hepatic tissue following the protocol of RNeasy Mini Kit (Qiagen, Heidelberg, Germany). The purity of total RNA was determined using a spectrophotometer (ND-1000, NanoDrop Technologies, Wilmington, Delaware, USA). Only highpurity samples (OD 260/280>1.8) were further used. Then, $0.5 \mathrm{mg}$ of total RNA was reversely transcribed into cDNA using QIAGEN 2 Step RT-PCR Kit, following the manufacturer's instructions. One $\mu \mathrm{L}$ of total cDNA was mixed with $12.5 \mu \mathrm{L} 2 \mathrm{x}$ SYBR-Green PCR mix with ROX (BioRad, California, USA), $5.5 \mu \mathrm{L}$ RNA free water, and $0.5 \mu \mathrm{L}(10 \mathrm{pmol} / \mu \mathrm{L})$ of each forward and reverse primers for the measured genes. The expression was normalized by an internal housekeeping control ( $\beta$-actin) gene.

The primer sequences were listed in Table 1. PCR reactions were carried out in a Rotor-Gene (Biometra, Gottingen, Germany). The real-time PCR reaction program included a $94^{\circ} \mathrm{C}$ enzyme activation step for $2 \mathrm{~min}$, followed by 40 cycles of $95^{\circ} \mathrm{C}$ denaturation for $15 \mathrm{sec}$, $60{ }^{\circ} \mathrm{C}$ annealing for $30 \mathrm{sec}$ and $72^{\circ} \mathrm{C}$ extension for $30 \mathrm{sec}$. The detection of a fluorescent product was carried out at the end of the $72{ }^{\circ} \mathrm{C}$ extension period. The amplification data were collected by the sequence detector and analyzed with sequence detection software. The quantitative fold changes in mRNA expression were determined relative to $B-$ actin mRNA levels in each corresponding group and calculated using the $2-\Delta \Delta \mathrm{Ct}$ method according to (25)

\section{Results}

Results showed in table 2 represented that, after one month of treatment with 200 and $400 \mathrm{mg} / \mathrm{kg} \mathrm{b}$. wt. of ZnONPs, there were a significant increase in the serum levels of liver enzymes (ALT, AST and ALP) activities with increase in the hepatic MDA level and decrease in the hepatic GSH concentration, GPx, GR, SOD and CAT activities. These changes was a dose dependent changes. This may indicates hepatic tissue destruction and induction of oxidative stress status. Co-treatment of rats by QE with ZnONPs success to ameliorate the destructive effect of ZnONPs especially in the group treated with 200 $\mathrm{mg} / \mathrm{kg} \mathrm{b}$.Wt. by decreasing the serum liver enzymes activities, decreasing MDA levels and improve the GSH concentrations and increase antioxidant enzymes activities which indicates its antioxidant ability.

Results in table 3 showed the fold change in the mRNA levels of some antioxidant genes. One month of treatment with 200 and $400 \mathrm{mg} / \mathrm{kg}$ b. wt. of ZnONPs, resulted in a significant decrease in the levels of gene expression of GPx, GR, SOD and CAT genes relative to $\beta$-actin gene especially with the high dose. QE cotreatment with ZnONPs success to improve the levels of gene expression of those genes which indicates its antioxidant properties.

\section{Histopathological investigation:}

1. Control and Qurecitin treated groups

The liver parenchyma of these groups was observed very homogenous consisting of numerous hepatic lobules that were difficult demarcated from each other's by a very thin connective tissue septa or trabeculae in between. Furthermore, the hepatic lobule appeared hexagonal in shape and had a central vein in their center. The major compartment of each hepatic lobule were the hepatocytes that appeared irregular polygonal or polyhedral shaped cells typically with single, central, large vesicular nucleus with fine dispersed chromatins in most cases. Hepatocytes were dorsally radiating from the central vein towards the periphery, the portal areas forming the hepatic cords. Moreover, the hepatic sinusoids were observed distributing in between the hepatic cords supplying the hepatocytes 
2. ZnONPs treated groups

The groups treated with ZnONPs showed severe stenosis, diffuse degeneration and necrosis of hepatic tissues with loss of the hepatic architectures in a percent related to their concentrations, as the pathological changes increased by increasing the dose. Fibrous tissue proliferation with antiinflammatory cells infiltration was observed within the parenchyma in the group treated with high doses of ZnONPs. Hexagonal lobules are centered on the central vein that exhibited moderate to severe congestion with the hepatic artery, sinusoids and Portal vein. Furthermore, disorganization of hepatic cords was observed. In addition, sever degenerative changes which were evident in numerous hepatocytes. The hepatocytes were enlarged, had light and foamy cytoplasm filled with vacuoles of variable size that were tended to form cystic degeneration.

3. ZnONPs + Qurecitin treated groups Regarding the Co-treated groups those are treated with ZnONPs in a dose of 200 $\mathrm{mg} / \mathrm{kg}$. b. wt. and $400 \mathrm{mg} / \mathrm{kg}$. bwt and QE, the liver of G5 was appeared looks like normal with normal hepatic parenchyma but showed mild stenosis within the hepatocytes cytoplasm and mild inflammation. Meanwhile, the liver of G6 was showed moderate stenosis, moderate degeneration of hepatic tissues, fibrous tissue proliferation with anti-inflammatory cells infiltration in the portal areas and moderate disorganization of hepatic cords.

\section{Discussion}

As a result of great technological achievement in the last decade and multiple uses of $\mathrm{ZnONPs}$ in different applications including cosmetics, paints, as drug carrier and filling in medical materials (26) also its uses in animal husbandry to improve the utilization of trace elements in animal diets $(27,28)$ and increased reports describing ZnONPs toxicity, our attention was directed to trying to evaluated the possible toxic effects of $\mathrm{ZnONPs}$ on hepatic tissue using different dosses; at the same time examining the possible ameliorative effect of an old flavonoid Qurecitin against the possible toxic effects.

The increase in the serum levels of liver enzymes due to ZnONPs treatment as explained obtained in our results (table 2) may be due to liver cell damage that confirmed also by our histopathologcal examination (Figure 2) as the increased levels of these enzymes in the blood serum used as an efficient indicator to liver damages and liver diseases (29). Mohamad (30), Bakhshiani and Fazilati (22) and many other reports supported our results.

Liver cells in the control and QE treated groups showed normal hepatic architectures with very homogenous hepatic lobules. Whereas, liver cells in the ZnONPs treated groups showed severe stenosis, diffuse degeneration and necrosis of hepatic tissues with loss of the hepatic architectures. Treatment with QE the amazing flavonoid in our experiment success to improve the cell status and hepatic tissue especially in the group treated with lower dose as the cells nearly normal hepatic parenchyma with mild stenosis which reflected on the serum liver enzymes activities that decreased by QE treatment (table 2).

Lipid peroxidation (LPO) is one of the main manifestations of oxidative damage (31). The increase in LPO represented by the significant increase in the levels MDA in our experiment in the ZnONPs treated groups according to the dose used (30.04 \pm 0.62 and $39.58 \pm 0.56 \mu \mathrm{mol} / \mathrm{g}$ tissue) when

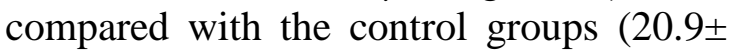
$0.45 \mu \mathrm{mol} / \mathrm{g}$ tissue) is most related to the ability of ZnONPs to augment LPO by enhancing the production of a reactive oxygen intermediate.

Free radicals are in fact potent deleterious agents causing cell death or other forms of irreversible damage, e.g., by modifying DNA base pairs causing mutagenesis, carcinogenesis and aging (32). Elevation of hepatic MDA in our study, supports the participation of free radical-induced oxidative cell injury in mediating ZnONPs 
toxicity (33). Ma et al., (34) reported also that, increased $\mathrm{Zn}^{2+}$ was incriminated in the activation of ROS production through interaction with membrane lipids damaging the cell membrane, DNA and proteins.

Interestingly, the rats that were supplemented QE together with ZnONPs showed less toxic effects or even no toxic effect in most of studied parameters. Treatment with QE success to decrease the MDA levels in the ZnONPs treated groups, therefore; the fact that $\mathrm{QE}$ decreased LPO might mean that it has an antioxidant effect (35).

In evaluating the non-enzymatic antioxidant GSH levels during I/P injection of ZnONPs, there was a significant decrease in the hepatic GSH levels $(17.5 \pm 0.31$ and $13.34 \pm 0.35)$ in the groups treated with 200 and $400 \mathrm{mg} / \mathrm{kg}$ b. wt. of ZnONPs respectively when compared with control group (22.08 \pm 0.5$)$. This decrease may be due to the oxidative stress produced from ZnONPs administration that causing exhaustion of GSH levels. There is an inverse relationship between GSH levels and LPO (36). Younes and Seigers (37) have reported that once the GSH concentration is depleted to $20 \%$ of its original content, LPO is initiated.

By evaluating the Glutathione enzyme system, our study showed also that, I/P injection of $\mathrm{ZnONPs}$ resulted in a significant decrease in the hepatic GPx and GR activities (table 2) and in the same line their gene expression (table 3). As oxidative damage is mediated by free radicals, it was necessary to investigate the status of endogenous antioxidant enzymes like SOD and CAT, which are the first line of defense against free radical damage under oxidative stress conditions (38).

The Hepatic levels of SOD and CAT were significantly decreased in a dose dependent manner after I/P injection of $\mathrm{ZnONPs,}$ therefore, the conversion of superoxide radicals into $\mathrm{H}_{2} \mathrm{O}_{2}$ and the breakdown to $\mathrm{H}_{2} \mathrm{O}_{2}$ into $\mathrm{H}_{2} \mathrm{O}$ and $\mathrm{O}_{2}$ by
CAT is slowed down leading to the production of hydroxyl radicals (39). The decrease in the activity of antioxidant enzymes might have resulted from the oxidative modification of genes that control these enzymes (40) and this already observed in our experiment when we examine gene expression of antioxidant enzymes as found in table 2. This is proved by the reduction of mRNA expression of endogenous antioxidant enzymes due to ZnONPs treatment in many studies (41).

Interestingly, the $\mathrm{QE}$ co-treatment ameliorated ZnONPs induced hepatic oxidative damage through restoring GPx, GR, SOD and CAT mRNA levels towards the control values. At the same time, $\mathrm{QE}$ mitigated hepatic oxidative damage induced by ZnONPs through improvement of those antioxidant enzyme activates as showed in table 2. The ameliorative effect of QE may be attributed to its free radical scavenging properties (42). Besides, QE is a more powerful antioxidant than other antioxidants such as vitamin $\mathrm{C}$, vitamin $\mathrm{E}$ and $\beta$-carotene (43). Several reports supported our results either in vivo (10, $44)$ or in vitro $(45,46)$.

From the above it may be concluded that, extensive use of ZnONPs can leads to hepatotoxicity represented by increase in the serum liver enzymes (ALT, AST and ALP), liver cell damage (stenosis, hepatic degeneration and inflammatory state) and oxidative stress (manifested by increase in the MDA levels, decrease in GSH and enzymatic antioxidant activates and gene expression). The use of natural flavonoid QE can improve the hepatic status through decreasing the serum liver enzyme levels, improving the cell state through its antioxidant property and its ability to scavenge free radicals that led to decrease in MDA with increase in other antioxidant.

\section{References}

1. Buzea C, Pacheco Blandino II, Robbie K. 2007: Nanomaterials and 
nanoparticles: sources and toxicity. Biointerphases; 2(4):MR17-71.

2. Lan Z, Yang W-X. 2012: Nanoparticles and spermatogenesis: how do nanoparticles affect spermatogenesis and penetrate the blood-testis barrier. Nanomedicine; 7(4):579-596.

3. Choi J, Kim H, Kim P, Jo E, Kim H-M, Lee M-Y, Jin SM, Park K. 2015: Toxicity of zinc oxide nanoparticles in rats treated by two different routes: Single intravenous injection and single oral administration. Journal of Toxicology and Environmental Health A; 78(4):226-243.

4. Rasmussen, JW. ; Martinez, E.; Louka, P. and Wingett, DG. 2010: Zinc oxide nanoparticles for selective destruction of tumor cells and potential for drug delivery applications. Expert Opin Drug Deliv 7: 1063-1077.

5. Hackenberg, S.; Zimmermann, FZ.; Scherzed, A.; Friehs, G. Froelich, K. 2011: Repetitive exposure to zinc oxide nanoparticles induces dna damage in human nasal mucosa mini organ cultures. Environ Mol Mutagen 52: 582-589.

6. Teow, Y.; Asharani, PV. ; Hande, MP., Valiyaveettil, S. 2011: Health impact and safety of engineered nanomaterials. Chem Commun (Camb) 47: 7025-7038.

7. Wang, B.; Feng, W.; Wang, M.; Wang, T. and Gu, Y. 2008: Acute toxicological impact of nano-and submicron-scaled zinc oxide powder healthy adult mice. J Nanopart Res 10: 263-276.

8. Zheng, Y.; Li, R. and Wang, Y. 2009: In vitro and in vivo biocompability of $\mathrm{ZnO}$ nanoparticles. Int. J. Mod. Phys. B, 23, 1566-1571.

9. Pasupuleti, S.; Alapati, S.; Ganapathy, S.; Anumolu, G. and Pully, NR. 2012: Toxicity of zinc oxide nanoparticles through oral route. Toxicol Ind Health 28: 675-686.

10. Sharma, V.; Singh, P.; Pandey, AK.and Dhawan, A. 2012: Induction of oxidative stress, DNA damage and apoptosis in mouse after liver sub-acute oral exposure to zinc oxide nanoparticles. Mutat Res Gen Tox En 745:84-91.

11. Ho M, Wu KY, Chein HM, Chen LC, Cheng TJ. 2011: Pulmonary toxicity of inhaled nanoscale and fine zinc oxide particles: mass and surface area as an exposure metric. Inhal Toxicol; 23 (14):947-956.

12. Lanzafame FM, La Vignera S, Vicari E, Calogero AE. 2009: Oxidative stress and medical antioxidant treatment in male infertility. Reprod Biomed Online; 19(5):638- 659.

13. Kuldip S., Ahluwalia P., 2005: Alteration in some antioxidant enzymes in cardiac tissue upon monosodium glutamate (MSG) administration to adult male mice. Indian Journal of Clinical Biochemistry, 20 (1) 43-46.

14. Zini A, Al-Hathal N. 2011: Antioxidant therapy in male infertility: fact or fiction? Asian J Androl; 13(3):374-381.

15. Davis JM, Murphy EA, Carmichael MD, Davis B. 2009: Querectin increases brain and muscle mitochondrial biogenesis and exercise tolerance.AmJ Physiol Regul Integr Comp Physiol; 296(4):R1071-R1077.

16. Naderi GA, Asgary S, SarrafZadegan N, Shirvany H. 2003: Antioxidant effect of flavonoids on the susceptibility of LDL oxidation. Mol Cell Biochem; 246(1-2):193-196.

17. Kang JT, Moon JH, Choi JY, Park SJ, Kim SJ, Saadeldin IM, Lee BC. 2016: Effect of antioxidant flavonoids (querectin and taxifolin) on in vitro maturation of porcine oocytes. AsianAustralas J Anim Sci; 29(3):352-358.

18. Kamada, C.; da Silva, E. L.; Ohnishi-Kameyama, M.; Moon, J. H.; Terao, J. 2005: Attenuation of lipid peroxidation and hyperlipidemia by quercetin glucoside in the aorta of highcholesterol-fed rabbit. Free. Radic. Res. 39:185-194. 
19. Murakami, A.; Ashida, H.; Terao, J. 2008: Multitargeted cancer prevention by quercetin. Cancer Lett. 269:315-325.

20. Youdim, K. A.; Shukitt-Hale, B.; Joseph, J. A. 2004: Flavonoids and the brain: interactions at the blood-brain barrier and their physiological effects on the central nervous system. Free Radic. Biol. Med. 37:1683-1693.

21. Renugadevi J, Prabu SM. 2010: Quercetin protects against oxidative stress-related renal dysfunction by cadmium in rats. Exp Toxicol Pathol 62:471-481.

22. Bakhshiani S., Fazilati M. 2014: Vitamin $\mathrm{C}$ can reduce toxic effects of Nano Zinc Oxide. Int. Res. J. Biological Sci. Vol. 3(3), 65-70.

23. Bancroft, JD., Gamble M, eds. 2008: Theory and Practice of Histological 551 Techniques. 6th ed. Philadelphia: Churchill Livingstone/ Elsevier.

24. Ali A, Afifi M, Abdelazim A, Mosleh Y 2014: Quercetin and omega 3 ameliorate oxidative stress induced by aluminum chloride in the Brain. J Mol Neurosci, 53, 654-660.

25. Litvak, K.J., Schmittgen, T.D., 2001: Analysis of relative gene expression data using real-time quantitative PCR and the 2 (- Delta Delta C (T) method. Methods, 25:402-408.

26. Oberdörster G, Oberdörster E, and Oberdörster J. 2005: Nanotoxicology: An Emerging Discipline Evolving from Studies of Ultrafine Particles. Environmental Health Perspectives; 113:823-839.

27. Scott, NR. 2005: Nanotechnology and animal health. Rev Sci Tech 24(1):425-432.

28. Scheerlinck, JP. Gloster, S., Gamvrellis, A.; Mottram, PL. Plebanski, M. 2006: Systemic immune responses in sheep, induced by a novel nano-bead adjuvant. Vaccine 24(8):1124-1131.

29. Fu Y., Zheng S.h., Lin J., Ryerse J., 2008: Curcumin Protects the Rat Liver from CCl4-Caused Injury and Fibrogenesis by Attenuating Oxidative
Stress and Suppressing Inflammation, Mol Pharmacol., 73, 399-409.

30. Mohamad F. 2013: Investigation toxicity properties of zinc oxide nanoparticles on liver enzymes in male rat. European Journal of Experimental Biology, 3(1):97-103.

31. Anane R, Creppy EE. 2001: Lipid peroxidation as pathway of aluminum cytotoxicity in human skin fibroblast cultures: prevention by superoxide dismutase + catalase and vitamins $\mathrm{E}$ and C. Hum Exp Toxicol 20:477-481.

32. Dizdaroglu $\mathrm{M}$, Jaruga $\mathrm{P}$, BirinciogluM, Rodriguez H. 2002: Free radical induced damage to DNA; mechanisms and measurement. Free Radic Biol Med 32(11):1102-1115.

33. Zhao, CY. ; Tan, SX. ; Xiao, XY. ; Qiu, XS. ; Pan, JQ. Tang, ZX. 2014: Effects of dietary zinc oxide nanoparticles on growth performance and antioxidative status in broilers. Biol Trace Elem Res. 160(3):361-7.

34. Ma LL, Liu J, Li N, Wang J, Duan YM, Yan JY, Liu HT, Wang H, Hong FS. 2010: Oxidative Stress in the Brain of Mice Caused by Translocated Nanoparticulate $\mathrm{TiO} 2$ Delivered to the Abdominal Cavity. Biomaterials; 31:99105.

35. Omer C, Mehmet $\mathrm{K}$, Ferah A, Kuriulus C, Betul K, Omer Y. 2004: Protective effects of quercetin, a flavonoid antioxidant, in absolute ethanol-induced acute gastric ulcer. Eur J Gen Med 1(3):37-42.

36. McCay P.B., Gibson D.D., Fong K.L.,Hornbrok K.R., 1976: Effect Of Glutathione peroxidase activity on lipid peroxidation in biological membrans. Biochemi. Biophys. Acta 431, 459-468.

37. Younes, M., C. P. Seigers 1981: Mechanistic aspects of enhanced lipid peroxidation following glutathione depletion in vivo. Chem. Biol. Interact. 34, 257-266.

38. Benzi G, Marzatico F, Pastoris O, Villa RF. 1989: Relationship between aging, drug treatment and the cerebral 
enzymatic antioxidant system. Exp Gerontol 24:137-148.

39. Good PF, Werner P, Hsu A, Olanow CW, Perl DP. 1996: Evidence for neuronal oxidative damage in Alzheimer's disease. Am J Pathol 140:621-628.

40. Nirmala RN, Shankarbhat K, Urban D. 2013: Effect of long term administration of aluminum chloride on oxidative stress and acetyl-cholinesterase activity in rat brains. IJPBS 3(1):616622.

41. Gonzalez-Muñoz MJ,Meseguer I, Sanchez-Reus MI, Schultz A, Olivero R, Benedí J et al., 2008: Beer consumption reduces cerebral oxidation caused by aluminum toxicity by normalizing gene expression of tumor necrotic factor alpha and several antioxidant enzymes. Food Chem Toxicol 46:1111-1118.

42. Anjaneyulu M, Chopra K. 2004: Quercetin, an anti-oxidant bioflavonoid, attenuates diabetic nephropathy in rats. Clin Exp Pharmacol Physiol 31:244-248.
43. Rice-Evans CA, Miller NJ, Paganga G. 1996: Structure antioxidant activity relationships of flavonoids and phenolic acids. Free Radic Biol Med 20:933-956.

44. Syama S, Reshma SC, Sreekanth

PJ, VarmaHK, Mohanan PV. 2013:

Effect of zinc oxide nanoparticles on cellular oxidative stress and antioxidant defense mechanisms in mouse liver.

Toxicol Environ Chem; 95(3):495-503. 45. Syama S, Sreekanth PJ,VarmaHK, Mohanan PV. 2014: Zinc oxide nanoparticles induced oxidative stress in mouse bone marrow mesenchymal stem cells. Toxicol Mech Methods; 24(9):644653.

46. Xia T, Kovochich M, Liong M, M“adler L, Gilbert B, Shi H, Yeh JI, Zink JI, Nel AE. 2008: Comparison of the mechanism of toxicity of zinc oxide and cerium oxide nanoparticles based on dissolution and oxidative stress properties. ACS Nano; 2(10):2121-2134.

Table (1): Primers used in determination of the gene expression of the selected genes:

\begin{tabular}{|c|c|c|c|}
\hline Gene & Primers & $\begin{array}{c}\text { Product } \\
\text { length(bp) }\end{array}$ & $\begin{array}{c}\text { Accession } \\
\text { no. }\end{array}$ \\
\hline \multirow{2}{*}{$\begin{array}{l}\text { Glutathione } \\
\text { peroxidase }\end{array}$} & F 5'-CACAGTCCACCGTGTATGCC-3' & \multirow[b]{2}{*}{292} & \multirow[b]{2}{*}{ S50336.1 } \\
\hline & R5'-AAGTTGGGCTCGAACCCACC-3' & & \\
\hline \multirow{2}{*}{$\begin{array}{l}\text { Glutathione } \\
\text { reductase }\end{array}$} & F 5'-CCATGTGGTTACTGCACTTCC-3' & \multirow[t]{2}{*}{171} & \multirow[t]{2}{*}{ NM_053906 } \\
\hline & R 5'GTTCCTTTCCTTCTCCTGAGC-3' & & \\
\hline \multirow{2}{*}{$\begin{array}{c}\text { Superoxide } \\
\text { dismutase }\end{array}$} & F 5'-ATGGGGACAATACACAAGGC-3' & \multirow[b]{2}{*}{225} & \multirow[b]{2}{*}{ Z21917.1 } \\
\hline & R 5'-TCATCTTGTTTCTCGTGGAC-3' & & \\
\hline \multirow[t]{2}{*}{ Catalase } & F 5'-GTCCGATTCTCCACAGTCGC-3' & \multirow[b]{2}{*}{272} & \multirow[b]{2}{*}{ AH004967.1 } \\
\hline & R 5'-CGCTGAACAAGAAAGTAACCTG-3' & & \\
\hline \multirow[t]{2}{*}{ B-actin } & F 5'-TCACTATCGGCAATGTGCGG-3' & \multirow[b]{2}{*}{260} & \multirow[b]{2}{*}{ NM_007393 } \\
\hline & R 5'-GCTCAGGAGGAGCAATGATG-3' & & \\
\hline
\end{tabular}


Table (2): Effect of Qurecitin and/or ZnONPs on serum ALT, AST, ALP activities, hepatic MDA and GSH concentrations and Hepatic GPx, GR, SOD and CAT activities.

\begin{tabular}{|c|c|c|c|c|c|c|}
\hline Groups & $\begin{array}{l}\text { Control } \\
\text { group }\end{array}$ & QE group & $\begin{array}{c}200 \\
\mathrm{mg} / \mathrm{Kg} \\
\mathrm{ZnONPs}\end{array}$ & $\begin{array}{l}400 \mathrm{mg} / \mathrm{kg} \\
\text { ZnONPs }\end{array}$ & $\begin{array}{l}\mathrm{QE}+200 \\
\mathrm{mg} / \mathrm{Kg} \\
\mathrm{ZnONPs}\end{array}$ & $\begin{array}{c}\mathrm{QE}+400 \\
\mathrm{mg} / \mathrm{kg} \\
\mathrm{ZnONPs}\end{array}$ \\
\hline ALT (U/L) & $36.8 \pm 1.36^{\mathrm{d}}$ & $\begin{array}{l}33.7 \pm \\
1.25^{\mathrm{d}}\end{array}$ & $54.6 \pm 1.5^{b}$ & $71.2 \pm 1.43^{\mathrm{a}}$ & $41.9 \pm 1.08^{\mathrm{c}}$ & $\begin{array}{l}51.7 \pm \\
0.88^{\mathrm{b}}\end{array}$ \\
\hline AST (U/L) & $30.7 \pm 0.66^{\mathrm{d}}$ & $\begin{array}{l}27.0 \pm \\
0.92^{\mathrm{e}}\end{array}$ & $\begin{array}{l}46.2 \pm \\
1.63^{\mathrm{b}}\end{array}$ & $62.0 \pm 1.9^{\mathrm{a}}$ & $32.8 \pm 0.84^{\mathrm{d}}$ & $\begin{array}{l}40.6 \pm \\
0.64^{\mathrm{c}}\end{array}$ \\
\hline ALP (U/L) & $\begin{array}{c}117.2 \pm \\
1.18^{\mathrm{e}}\end{array}$ & $\begin{array}{c}114.6 \pm \\
0.86^{\mathrm{e}}\end{array}$ & $\begin{array}{l}136.5 \pm \\
1.39^{\mathrm{b}}\end{array}$ & $\begin{array}{c}156.9 \pm \\
1.72^{\mathrm{a}}\end{array}$ & $\begin{array}{l}122.7 \pm \\
0.98^{\mathrm{d}}\end{array}$ & $\begin{array}{c}131.7 \pm \\
0.92^{\mathrm{c}}\end{array}$ \\
\hline $\begin{array}{l}\text { MDA }(\mu \mathrm{mol} / \mathrm{g} \\
\text { tissue })\end{array}$ & $20.9 \pm 0.45^{\mathrm{e}}$ & $\begin{array}{l}18.3 \pm \\
0.38^{\mathrm{f}}\end{array}$ & $\begin{array}{c}30.04 \pm \\
0.62^{\mathrm{c}}\end{array}$ & $\begin{array}{c}39.58 \pm \\
0.56^{\mathrm{a}}\end{array}$ & $27.7 \pm 0.36^{\mathrm{d}}$ & $\begin{array}{l}32.6 \pm \\
0.55^{\mathrm{b}}\end{array}$ \\
\hline $\begin{array}{c}\mathrm{GSH}(\mathrm{mg} / \mathrm{g} \\
\text { tissue) }\end{array}$ & $22.08 \pm 0.5^{\mathrm{b}}$ & $\begin{array}{c}26.47 \pm \\
0.54^{\mathrm{a}}\end{array}$ & $\begin{array}{l}17.5 \pm \\
0.31^{\mathrm{c}}\end{array}$ & $\begin{array}{c}13.34 \pm \\
0.35^{\mathrm{d}}\end{array}$ & $21.6 \pm 0.57^{b}$ & $\begin{array}{l}18.7 \pm \\
0.43^{\mathrm{c}}\end{array}$ \\
\hline $\begin{array}{c}\text { GPx }(\mu \mathrm{mol} \\
\text { NADPH/mg } \\
\text { protein })\end{array}$ & $\begin{array}{c}50.83 \pm \\
0.48^{\mathrm{a}}\end{array}$ & $\begin{array}{l}51.1 \pm \\
0.43^{\mathrm{a}}\end{array}$ & $\begin{array}{c}23.07 \pm \\
0.54^{\mathrm{d}}\end{array}$ & $\begin{array}{l}16.28 \pm \\
0.21^{\mathrm{e}}\end{array}$ & $41.7 \pm 0.62^{b}$ & $\begin{array}{c}32.58 \pm \\
1.17^{\mathrm{c}}\end{array}$ \\
\hline $\begin{array}{c}\mathrm{GR}(\mathrm{U} / \mathrm{g} \\
\text { tissue) }\end{array}$ & $\begin{array}{l}22.14 \pm \\
0.37^{\mathrm{ab}}\end{array}$ & $\begin{array}{c}23.07 \pm \\
0.54^{\mathrm{a}}\end{array}$ & $\begin{array}{c}17.29 \pm \\
0.91^{\mathrm{c}}\end{array}$ & $11.21 \pm 0.4^{\mathrm{e}}$ & $\begin{array}{c}21.13 \pm \\
0.29^{\mathrm{b}}\end{array}$ & $\begin{array}{l}18.2 \pm \\
0.28^{c}\end{array}$ \\
\hline $\begin{array}{l}\text { SOD }(\mathrm{eu} / \mathrm{mg} \\
\text { protein) }\end{array}$ & $\begin{array}{c}21.73 \pm \\
0.29^{\mathrm{a}}\end{array}$ & $\begin{array}{c}22.31 \pm \\
0.39^{\mathrm{a}}\end{array}$ & $\begin{array}{l}16.99 \pm \\
0.266^{\mathrm{d}}\end{array}$ & $\begin{array}{c}11.52 \pm \\
0.18^{\mathrm{e}}\end{array}$ & $\begin{array}{c}20.19 \pm \\
0.24^{\mathrm{b}}\end{array}$ & $\begin{array}{l}17.8 \pm \\
0.22^{\mathrm{c}}\end{array}$ \\
\hline $\begin{array}{c}\text { CAT ( } \mu \text { mol } \\
\mathrm{H}_{2} \mathrm{O}_{2} \\
\text { decomposed } \\
\text { /gm tissue })\end{array}$ & $\begin{array}{c}145.7 \pm \\
0.73^{b}\end{array}$ & $\begin{array}{r}148.4 \pm \\
0.58^{\mathrm{a}}\end{array}$ & $\begin{array}{l}136.9 \pm \\
0.95^{\mathrm{c}}\end{array}$ & $\begin{array}{l}117.9 \pm \\
0.81^{\mathrm{d}}\end{array}$ & $\begin{array}{c}144.6 \pm \\
0.95^{\mathrm{b}}\end{array}$ & $\begin{array}{c}136.5 \pm \\
0.67^{\mathrm{c}}\end{array}$ \\
\hline
\end{tabular}

Means $\pm S E$ within the same rows carrying different superscripts are significant at $(\boldsymbol{P} \leq 0.05)$.

Table (3): Effect of Qurecitin and/or ZnONPs on mRNA expression levels of hepatic GPx, GR, SOD and CAT genes.

\begin{tabular}{|c|c|c|c|c|c|c|}
\hline Groups & $\begin{array}{c}\text { Control } \\
\text { group }\end{array}$ & QE group & $\begin{array}{c}200 \mathrm{mg} / \mathrm{Kg} \\
\text { ZnONPs }\end{array}$ & $\begin{array}{c}400 \mathrm{mg} / \mathrm{kg} \\
\text { ZnONPs }\end{array}$ & $\begin{array}{c}\text { QE+ 200 } \\
\mathrm{mg} / \mathrm{Kg} \\
\text { ZnONPs }\end{array}$ & $\begin{array}{c}\text { QE+ 400 } \\
\mathrm{mg} / \mathrm{kg} \\
\text { ZnONPs }\end{array}$ \\
\hline GPx & $1 \pm 0.01^{\mathrm{b}}$ & $1.19 \pm$ & $0.53 \pm$ & $0.345 \pm$ & $0.79 \pm$ & $0.532 \pm$ \\
& & $0.02^{\mathrm{a}}$ & $0.013^{\mathrm{d}}$ & $0.012^{\mathrm{e}}$ & $0.017^{\mathrm{c}}$ & $0.016^{\mathrm{d}}$ \\
\hline GR & $1 \pm 0.01^{\mathrm{a}}$ & $1.01 \pm$ & $0.892 \pm$ & $0.618 \pm$ & $0.937 \pm$ & $0.784 \pm$ \\
& & $0.016^{\mathrm{a}}$ & $0.02^{\mathrm{c}}$ & $0.018^{\mathrm{e}}$ & $0.024^{\mathrm{b}}$ & $0.042^{\mathrm{d}}$ \\
\hline SOD & $1 \pm 0.08^{\mathrm{a}}$ & $1.107 \pm$ & $0.752 \pm$ & $0.534 \pm$ & $0.879 \pm$ & $0.652 \pm$ \\
& & $0.12^{\mathrm{a}}$ & $0.04^{\mathrm{c}}$ & $0.06^{\mathrm{e}}$ & $0.043^{\mathrm{b}}$ & $0.052^{\mathrm{d}}$ \\
\hline CAT & $1 \pm 0.01^{\mathrm{b}}$ & $1.19 \pm$ & $0.53 \pm$ & $0.345 \pm$ & $0.79 \pm$ & $0.532 \pm$ \\
& & $0.02^{\mathrm{a}}$ & $0.013^{\mathrm{d}}$ & $0.012^{\mathrm{e}}$ & $0.017^{\mathrm{c}}$ & $0.016^{\mathrm{d}}$ \\
\hline
\end{tabular}

Means \pm S.E within the same rows carrying different superscripts are significantly different at $(P \leq 0.05)$. 


\section{Histopathological investigation:}
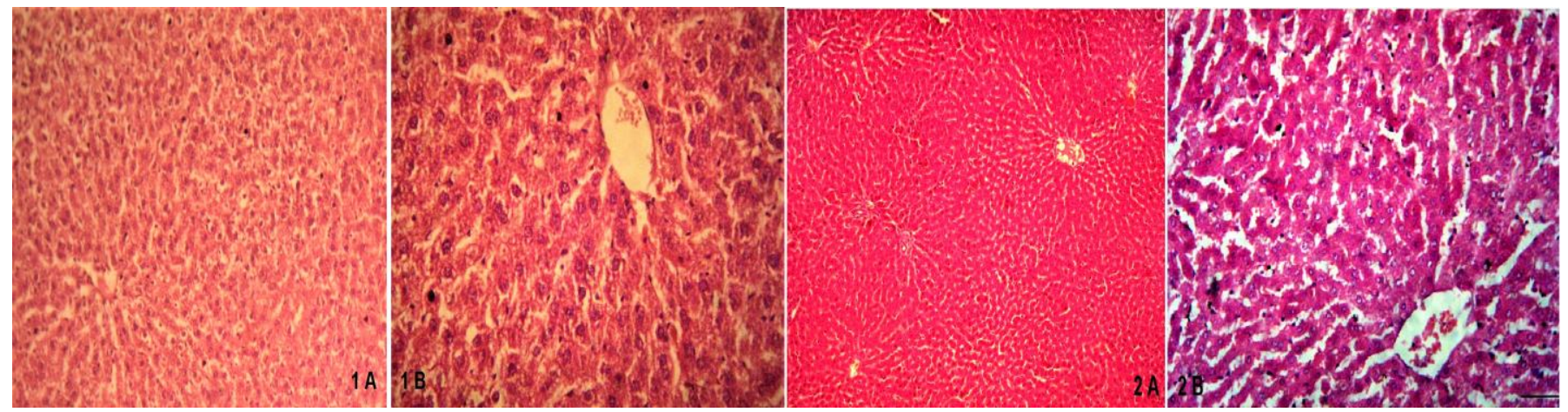

Figure 1: Histopathological examination of hepatic tissues in Control and QE treated groups: The liver of control (1A, 1B) and $\mathrm{QE}$ treated group (2A, 2B) revealed normal and intact hepatocyte and sinusoidal architectures.
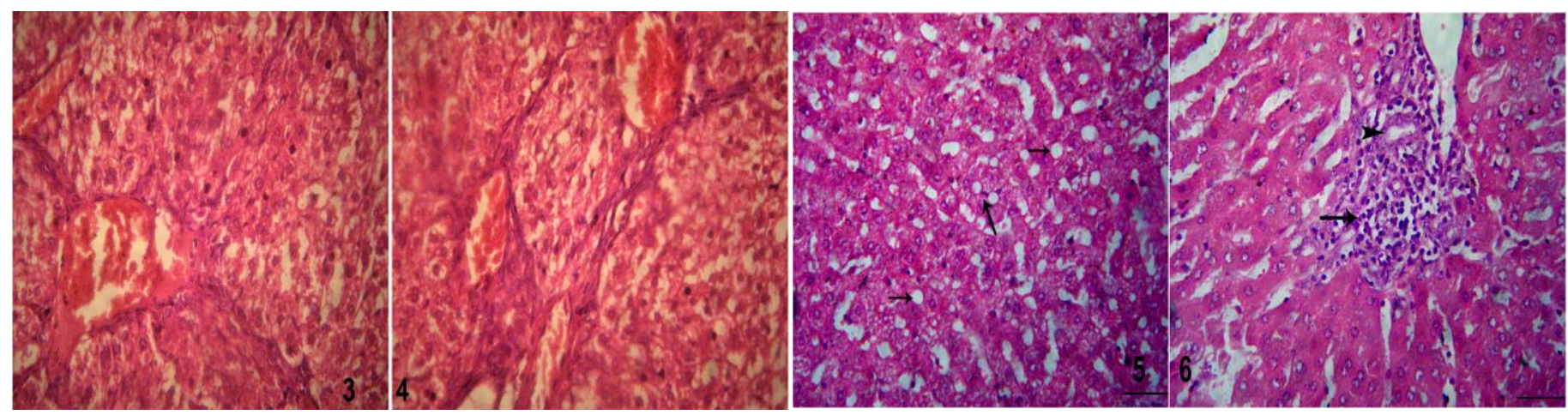

Figure 2: Histopathological examination of hepatic tissues in ZnONPs and QE Co-treated groups: The liver of G3 (group treated with $200 \mathrm{mg} / \mathrm{kg}$ BWT. ZnONPs) (3), G4 (group treated with $400 \mathrm{mg} / \mathrm{kg}$ BWT. ZnONPs) (4), G5 (group treated with $200 \mathrm{mg} / \mathrm{kg}$ BWT. ZnONPs $+50 \mathrm{mg} / \mathrm{kg} \mathrm{BWT}$ of Qurecitin) (5), G6 (group treated with $200 \mathrm{mg} / \mathrm{kg}$ BWT. ZnONPs $+50 \mathrm{mg} / \mathrm{kg}$ BWT of Qurecitin) (6). 